\title{
Mycorrhizal inoculation as an alternative in the ecological production of tomato (Lycopersicon esculentum Mill.)
}

\author{
Agnieszka Jamiołkowska1, Ali Hamood Thanoon ${ }^{2}$, Barbara Skwaryło-Bednarz ${ }^{1 *}$, Elżbieta Patkowska1, \\ and Elżbieta Mielniczuk ${ }^{1}$
}

${ }^{1}$ Department of Plant Protection, University of Life Sciences in Lublin, Leszczyńskiego 7, 20-069 Lublin, Poland

${ }^{2}$ Department of Plant Protection, College of Agriculture and Forestry, University of Mosul, 41002 Mosul, Iraq

Received October 24, 2019; accepted February 14, 2020

\begin{abstract}
The aim of study was to investigate the effect of two mycorrhizal fungus species Claroideoglomus etunicatum and Rhizophagus intraradices on the uptake of macronutrients and on the growth and yield of tomato hybrid plants cultivated in an ecological system. The experiment was carried out at an ecological farm in Grądy in the Lublin province of Poland, for three years (2015-2017). The experimental treatments included plants inoculated with Claroideoglomus etunicatum, Rhizophagus intraradices and plants without mycorrhizal inoculation used as a control. The mycorrhization of tomato roots with Claroideoglomus etunicatum and Rhizophagus intraradices resulted in an improved uptake of $\mathrm{Ca}$ and $\mathrm{K}$ through the plants. The length of the tomato roots, especially for the cultivars treated with Claroideoglomus etunicatum, were statistically longer than those of the control. Tomato roots inoculation with both of the studied mycorrhizal fungus strains significantly influenced the number of tomato leaves and improved the health status of the plant. The yield of tomato was not significantly affected by mycorrhization but Claroideoglomus etunicatum, to a greater extent than Rhizophagus intraradices reduced the yield of diseased fruit compared to the control. Among the studied mycorrhizal fungus species, better results were obtained with the application of Claroideoglomus etunicatum as compared with Rhizophagus intraradices for all examined features. Mycorrhizal inoculation contributed to the better growth of the plants, it improved their health and may be beneficially applied in the ecological production of tomatoes.

Keywords: nutrition, tomato, ecological production, mycorrhizal inoculation
\end{abstract}

*Corresponding author e-mail: barbara.skwarylo@up.lublin.pl

\section{INTRODUCTION}

Tomato (Lycopersicon esculentum Mill.) is one of the most important vegetable plants in the world (Nicola et al., 2009; Panthee and Chen, 2010; FAOSTAT, 2014). It is widely cultivated in tropical, subtropical and temperate climates and thus ranks third in terms of world vegetable production (FAOSTAT, 2014). Diseases are a major limiting factor for tomato production. The most important diseases are those caused by pathogens that include fungi, bacteria and viruses. These diseases are a major limiting factor and can be severe, reducing tomato yield and quality.

Due to the drawbacks of the chemical plant protection method, consumer pressure and the introduction of international food safety standards (IFSS), a need has arisen for farmers to change their production and marketing practices. As required by the IFSS, agricultural producers may consider it necessary to use alternative pest management methods, especially in ecological production. This production system takes into account biological methods, understood not only as direct protection, but also as the use of the natural processes of self-regulation. One of these methods is biological control, which provides environmentally safe ways to reduce the adverse effects of pathogens on crops. Potential biological control agents include arbuscular mycorrhizal fungi (AM Fungi) (Al-Askar and Rashad, 2010). AM Fungi are a promising source for improving sustainable food production and increasing human

(C) 2020 Institute of Agrophysics, Polish Academy of Sciences 
nutritional needs (Hart et al., 2015). AM Fungi used in horticulture are an effective means of improving plant growth (Oseni et al., 2010). Mycorrhiza is a natural phenomenon offering many benefits for farmers and, therefore, may be useful in sustainable plant development (Conversa et al., 2007; Candido et al., 2015). AM Fungi are a major component of most plant rhizospheres and they play an important role in reducing the occurrence of plant diseases.

Different studies indicate that AM Fungi increase the nutrient uptake of plants. This improves the resistance of plants to pathogens through compensation for the symptoms of infection, and the morphological and biochemical changes in plants, as well as the increase in the number of antagonistic microorganisms in the rhizosphere (Kapoor, 2008; Song et al., 2015). Mycorrhizal fungi stimulate plant defence reactions at the initial stages of symbiosis (Paszkowski, 2006). The modulation of plant defence during the establishment of mycorrhiza causes a pre-conditioning of tissues by effectively activating the defence mechanisms of the plants, which is known as the priming phenomenon (Pozo and Azcón-Aguilar, 2007). It plays a major role in mycorrhiza-induced resistance (Jung et al., 2012). Song et al. (2015) found that plant mycorrhization increases tomato plant resistance to early infection by Phytophthora infestans by activating the jasmonic acid (JA) signaling pathway.

Numerous studies have confirmed that AM Fungi enhance plant resistance against various pathogens (Harrier and Watson, 2004; Pozo et al., 2005; Bi et al., 2007). Mycorrhizal colonization improved tomato resistance to wilt diseases caused by Fusarium oxysporum f. sp. lycopersici and increased tomato resistance to the foliar disease of early blight caused by Alternaria solani (Akköprü and Demir, 2005; Fritz et al., 2006). The appropriate management of AM Fungi has the potential to provide sustainability in agricultural systems for crop disease management (Zeng, 2006; Liu et al., 2007). However, the mechanism of disease resistance induced by AM Fungi remains elusive. It is well known that transcriptional reprogramming occurs in the host-plant upon mycorrhizal colonization (Jung et al., 2012; Lopez-Ráez et al., 2010). Mycorrhizal fungi control not only soil-borne pathogens but evidence has been presented which shows the suppression of leaf attacking pathogens. Fritz et al. (2006) found that the protective effect of mycorrhiza against the development of tomato leaf spots caused by $A$. solani has an effect equivalent to induced systemic resistance. Common mycorrhizal networks between tomato plants provide the protection of neighbours against early blight (Song et al., 2015). In recent times, the system of the classification of fungi forming or considered to form arbuscular mycorrhiza placed them in phylum Glomeromycota and class Glomeromycetes with four orders (Archaeosporales, Diversisporales, Glomerales, and Paraglomerales), ten families and thirteen genera (Walker et al., 2007; Palenzuela et al., 2008; Oehl et al., 2011; Błaszkowski, 2012).
Considering the above-mentioned aspects, it is believed that there is a need to study and select the species of mycorrhizal fungi which - when inoculated into the rhizosphere of tomato - will contribute to better plant nutrition, their improved growth and health status. Hence, the objectives of this study were to: I - determine the influence of AM Fungi on root colonization, II - investigate the variability of leaf nutrient content, growth and yield of tomato plants under the influence of the studied species of mycorrhizal fungi, III - determine which mycorrhizal fungus (MF) species will be better to use in the ecological production of tomato.

\section{MATERIALS AND METHODS}

The research work was carried out at an ecological farm located in Grady in the Lublin province, Poland $\left(51^{\circ} 05^{\prime} \mathrm{N}\right.$ latitude, $22^{\circ} 12^{\prime} \mathrm{E}$ longitude) in the years 2015-2017. The object of the studies included three cultivars of tomato hybrids (Lycopersicon esculentum Mill.) important for commercial production: 'Antalya F1' (Yuksel Tohomculuk Company in Turkey), 'Esmira F1' (Rijk Zwaan Company in Holland), 'Pelikan F1' (Seed and Nursery Company in Ożarów Mazowiecki in Poland) and two species of mycorrhizal fungi (MF): Claroideoglomus etunicatum (CE) (syn. Glomus etunicatum W.N. Becker \& Gerd) and Rhizophagus intraradices (RI) (syn. Glomus intraradices N.C. Schenck \& G.S. Sm.). MF spores were provided from the collection belonging to the Department of Agricultural Microbiology, the Institute of Soil Science and Plant Cultivation - National Research Institute in Puławy, Poland. The experiment was established in a plastic tunnel with the dimension of $6 \times 30 \times 2.80 \mathrm{~m}$. The experiment was carried out on albic luvisols (cutanic) soil (Kabała et al., 2019). In each year, organic nitrogen fertilizer (Bioilsa 12.5 - NaturalCrop Poland) was used before planting plants in a permanent place using a dose of $500 \mathrm{~kg} \mathrm{ha}^{-1}$. Tomatoes were grown in soil with the following parameters: $\mathrm{pH}$ in $\mathrm{H}_{2} \mathrm{O}$ 5.83-6.66 (KQ/PB-47); levels of available minerals: P-39.0-63.0 mg $\mathrm{kg}^{-1}$ f.w. of soil (KQ/PB-51); K-314.0-477 mg kg ${ }^{-1}$ f.w. of soil (KQ/PB-52); Mg-60.0-89.0 mg kg-1 f.w. of soil (KQ/ PB53); Ca-462.0-619.0 mg kg-1 f.w. of soil (KQ/PB-52); total nitrogen: 23.4-63.5 mg kg-1 f.w. of soil) (Chemical and Agricultural Station in Lublin). Cucurbitaceae plants (cucumber) were the preceding crops for each year of the study.

Tomato seedlings were produced in accordance with the generally accepted rules for this vegetable using horticultural soil (peat moss) and quartz sand at a ratio of 2:1 (Welbaum, 2015). Four week old seedlings (at the stage of three true leaves) were planted in a plastic tunnel in the first week of May where the distance between the rows was $0.80 \mathrm{~m}$, and the spacing between the plants in the row was $0.50 \mathrm{~m}$ $\left(2.5\right.$ plants $\left.\mathrm{m}^{2}\right)$. Before planting the plants in a permanent place, mycorrhizal inoculum was applied using 25-30 spores of MF in physiological saline solution $(5 \mathrm{ml})$ to the 
rhizosphere of each seedling (to a depth of $5 \mathrm{~cm}$ ). In each year of the studies, the field experiment was randomized in a complete block design as a two-factor experiment with five replicates and three treatments. The experimental treatments were: plants inoculated with C. etunicatum (CE), plants inoculated with $R$. intraradices (RI), plants without mycorrhizal inoculation as control (C). The abovementioned treatments were used for each of the tomato cultivars. Black film was used for mulching in the rows in order to protect plants from weeds. Plants were irrigated using drip irrigation depending on their requirements. No fertilization or chemical protection was applied during the vegetation period.

The colonization of roots by the tested mycorrhizal fungi (MF) was measured at the stage of full fructification of the tomato plants (BBCH 89). The evaluation of root colonization (\%) by MF was carried out using the Phillips and Hayman method (Phillips and Hayman, 1970). The percentage of root colonization was calculated when five plants were taken from each experimental combination. The lateral roots of these plants were selected, washed under tap water and cut into $0.5 \mathrm{~cm}$ fragments. Washing was performed, so that the mycelium and the spores, which are attached to the roots, would not be washed away. After cleaning, the root fragments were transferred into $10 \%$ $\mathrm{KOH}$ solution and boiled at $90^{\circ} \mathrm{C}$ for $1 \mathrm{~h}$. After cooling, the root fragments were washed in distilled water and transferred into $1 \% \mathrm{HCl}$ at $90^{\circ} \mathrm{C}$ for $20-30 \mathrm{~min}$ to acidify the roots. Next, the root fragments were washed in distilled water 2-3 times. They were stained with $0.05 \%$ trypan blue solution. The stained root fragments were placed in De-stain solution, then placed on a slide for the observation of the mycelium of MF under the microscope. The colonization of the roots with MF was estimated using the following formula (Phillips and Hayman, 1970) :

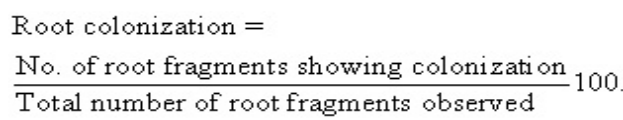

In order to measure the leaf nutrient content, samples of tomato leaves were collected at the stage of full fructification of the tomato plants (BBCH 89), from the top shoots (fourth leaf on the shoot top). 50 leaves were randomly selected in each experimental combination. After microwave mineralization of the plant material with $\mathrm{HNO}_{3}$, the magnesium $(\mathrm{Mg})$, potassium $(\mathrm{K})$ and calcium $(\mathrm{Ca})$ contents were estimated using Flame Atomic Absorption Spectroscopy (FAAS)64. The leaf nitrogen (N) concentration was determined using the Kjeldahl method following the procedures of Sadasivam and Manickam (2005).

The length of the stem and the number of leaves were measured at the beginning of fructification (BBCH 76) and at full fructification of the tomato plants (BBCH 89). The length of the root was measured at the stage of full fructification of the tomato plants (BBCH 89). Five plants from each experimental combination were chosen randomly for the calculations. The length of the stem and the root $(\mathrm{cm})$ was recorded as the average size obtained from the measurements, which were carried out for each experimental combination. In order to calculate the average number of leaves per plant, the total number of leaves was divided by the number of plants measured in a given experimental combination.

The disease index $(D I)$ was determined twice in the growing season: $\mathrm{BBCH} 76, \mathrm{BBCH} 89$. These parameters were measured for ten plants from each experimental combination using the authors' own 5 -degree scale: $0^{\circ}-$ no disease symptoms, $1^{\circ}$ - small yellow spots on the leaves covering up to $25 \%$ of the leaf area, $2^{\circ}$ - yellowish leaves and small necrotic spots on the leaves covering up to $50 \%$ of the leaf area, $3^{\circ}$ - necrotic spots on the leaves covering an area ranging from 50 to $75 \%$ of the leaf area, $4^{\circ}$ - extensive necrotic spots on the leaves covering over $75 \%$ of the leaf area, with wilting, dying leaves. The values obtained in degrees were converted to the disease index $(D I, \%)$ according to the Townsend-Heuberger formula (Wezel, 1948):

$$
D I=\frac{\sum n v}{N V} 100,
$$

where: $n$ is the number of plants assigned to the class, $v$ represents the numeric value of the scale, $N$ is the total number of the plants in the replication and $V$ is the numeric value of the highest scale.

Tomato fruit were harvested by hand from marked plants during the commercial harvest period (second 10-day period of July until the first 10-day period of October - BBCH 76-88), when the fruit reached the technological maturity stage indicated by the red colour. The harvest took place successively, every 7-14 days, at the phase of technological maturity of the fruit. The yielding parameters were calculated for each plant from the experimental combination on the basis of five replications. The fruit yield is presented in $\mathrm{kg} \mathrm{m}^{-2}$. The total yield included marketable fruit, fruit with disease symptoms and undersized fruit (with a weight of less than $30 \mathrm{~g}$ ).

The data were analysed using One-way Analysis of Variance (ANOVA) by using SAS Version 9.1 software (SAS Inst., Cary, N.C., USA). Group comparisons were made to determine if the variations among the means of parameters from various treatments were significantly different at a $5 \%$ significance level $(\mathrm{p} \leq 0.05)$.

\section{RESULTS}

The inoculation of roots with MF had an influence on the percentage of tomato root colonization. The degree of colonization depended on the species of fungus used for mycorrhization and the study year, but it did not depend on the tomato cultivar. Tomato roots, which were strongly colonized by $C$. etunicatum (GE-49.15\%) and $R$. intraradices (RI-46.52\%), differed significantly from the control 
(C-23.96\%) (Fig. 1). The degree of root colonization did not, however, depend on the species of the applied mycorrhizal fungus. The roots of the plants were colonized most in 2015 and least in 2017, and the differences were statistically significant (Fig. 1).

The measurement of the content of macronutrients in tomato leaves allowed for the evaluation of the influence of the tested MF on the extent of nutrient uptake from the soil. The application of $C$. etunicatum and $R$. intraradices within tomato roots resulted in an increase in the mean $\mathrm{K}$ content in the leaves of the studied tomato cultivars (CE$4.51 \mathrm{~g} \mathrm{~kg}^{-1}$ f.w., RI-4.34 $\mathrm{g} \mathrm{kg}^{-1}$ f.w.), as compared to the control (C-4.20 $\mathrm{g} \mathrm{kg}^{-1}$ f.w.), but they were not statistically
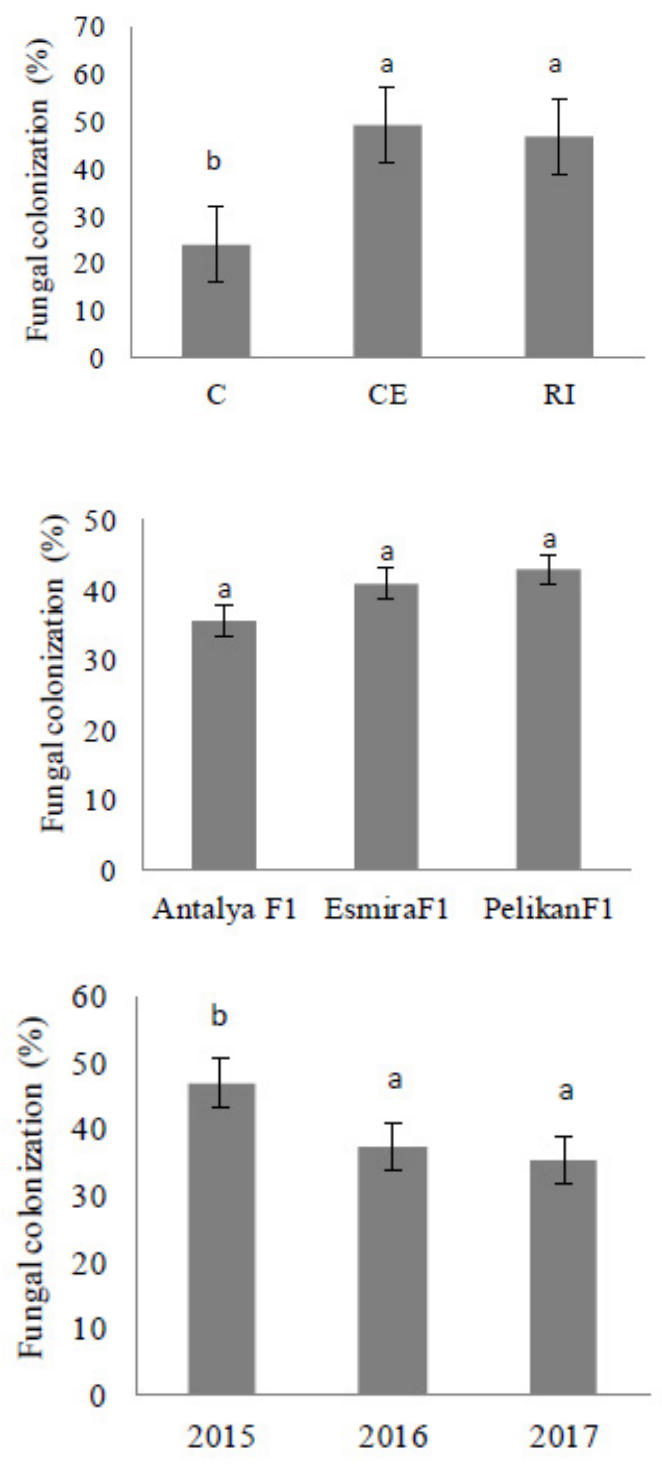

Fig. 1. Colonization of tomato roots by mycorrhizal fungi during the growing season 2015-2017 (\%); mean for years, experimental combinations, and cultivars; $\mathrm{C}-$ control, $\mathrm{CE}-C$. etunicatum, $\mathrm{RI}$ $-R$. intraradices; Error bars are the standard error of the means. The letters $(\mathrm{a}, \mathrm{b} \ldots)$ shown in the figure point to significant differences among the treatments at $\mathrm{p} \leq 0.05$ (Tukey's test). significant differences (Table 1). The content of $\mathrm{K}$ in the tomato leaves statistically depended on the cultivar used and the year of the study. Significant differences in the K content of the leaves were observed for cultivars 'Esmira $\mathrm{F}_{1}$ ' and 'Pelican $\mathrm{F}_{1}$ ', where the content of $\mathrm{K}$ was significantly higher after the application of $C$. etunicatum than in the control (Fig. 2).

A high content of $\mathrm{Ca}$ in the leaves was observed after the application of $R$. intraradices (RI-5.82 $\mathrm{g} \mathrm{kg}^{-1}$ f.w.) and $C$. etunicatum (CE-5.58 $\mathrm{g} \mathrm{kg}^{-1}$ f.w.), and the differences were statistically different from the control (C-5.27 $\mathrm{g} \mathrm{kg}^{-1}$ f.w.). The mean content of $\mathrm{Ca}$ in the tomato leaves also depended on the cultivar. The highest mean content of $\mathrm{Ca}$ was found for 'Esmira $\mathrm{F}_{1}$ ', while the lowest one occurred for 'Pelikan $\mathrm{F}_{1}$ ' (Table 1, Fig. 2).

The leaf $\mathrm{K}$ and $\mathrm{Ca}$ content during three years of studies was related not only to the presence of MF in the soil but also to the degree of root colonization (Fig. 3). Our results showed a positive linear relationship between the degree to which the roots were colonized by $C$. etunicatum and the mean $\mathrm{K}$ leaf content, but a negative correlation between the degree to which the roots were colonized by $R$. intraradices and the mean content of $\mathrm{K}$ in the leaves. By contrast, $\mathrm{Ca}$ leaf content increased significantly depending on the degree of root colonization by $R$. intraradices, while a very weak relationship was found between the degree of root colonization by $C$. etunicatum, and the mean content of $\mathrm{Ca}$ in tomato leaves.

The mean $\mathrm{N}$ concentration (\%) and mean $\mathrm{Mg}$ content in tomato leaves were not significantly affected by the application of the studied MF. On the other hand, the content of $\mathrm{N}$ and $\mathrm{Mg}$ in the leaves was related to the cultivar and year of cultivation (Table 1).

The data presented in Table 2 indicate that the inoculation of tomato seedlings with MF had a beneficial effect on the growth of the plants (length of stems and roots) although the results obtained were not statistically significant ( $\mathrm{p} \leq 0.05)$. The significant influence of MF on the number of tomato leaves was observed. During the three years of research work, no statistical differences were shown between the stem length of the tomatoes inoculated with MF and the control although the plants inoculated with $C$. etunicatum, $R$. intraradices were longer (respectively, GE-121.95 cm, RI-119.59 cm) than the control plants $(\mathrm{C}-110.97 \mathrm{~cm})$. The length of the tomato stems depended on the cultivar features and the period of measurement, and not on the species of mycorrhizal fungi. MF application, on the other hand, affected the length of the tomato roots. Plants inoculated with $C$. etunicatum had significantly longer stems (GE-50.95 cm), compared to the roots of the control plants $(\mathrm{C}-44.67 \mathrm{~cm})$, but they did not differ statistically from the roots of tomatoes inoculated with $R$. intraradices (RI- $48.32 \mathrm{~cm}$ ). The length of the tomato roots differed, depending on the year of cultivation, but this did not depend on the cultivar used. 
Table 1. Effects of tomato mycorrhization on leaf nutrient content during the growing season 2015-2017; means for experimental combinations, years and cultivars

\begin{tabular}{|c|c|c|c|c|c|}
\hline & \multirow{2}{*}{ Factor } & \multirow{2}{*}{$\begin{array}{c}\mathrm{N} \text { concentration } \\
(\%)\end{array}$} & \multicolumn{3}{|c|}{ Content ( $\mathrm{g} \mathrm{kg}^{-1}$ f.w.) } \\
\hline & & & $\mathrm{K}$ & $\mathrm{Ca}$ & $\mathrm{Mg}$ \\
\hline \multirow{6}{*}{$\begin{array}{l}\text { Experimental } \\
\text { combination }\end{array}$} & Control & $0.40 a^{*}$ & $4.20 \mathrm{a}^{*}$ & $4.27 \mathrm{a}^{*}$ & $0.61 \mathrm{a}^{*}$ \\
\hline & C. etunicatum & $0.40 \mathrm{a}$ & $4.51 \mathrm{a}$ & $5.58 \mathrm{~b}$ & $0.60 \mathrm{a}$ \\
\hline & R. intraradices & $0.41 \mathrm{a}$ & $4.34 \mathrm{a}$ & $5.82 \mathrm{~b}$ & $0.64 \mathrm{a}$ \\
\hline & $\operatorname{LSD}(\alpha=0.05)$ & 0.05 & 0.40 & 0.53 & 0.12 \\
\hline & $\mathrm{F}^{0}$ value & 0.239062 & 1.647761 & 28.24725 & 0.357287 \\
\hline & $P$ value & 0.787648 & 0.19575 & $3.1810^{-11}$ & 0.700132 \\
\hline \multirow{6}{*}{ Cultivar } & Antalya $\mathrm{F}_{1}$ & $0.37 a^{*}$ & $4.31 \mathrm{a}^{*}$ & $5.05 \mathrm{a}^{*}$ & $0.75 \mathrm{c}^{*}$ \\
\hline & Esmira $\mathrm{F}_{1}$ & $0.43 \mathrm{~b}$ & $4.03 \mathrm{a}$ & $5.83 \mathrm{~b}$ & $0.61 \mathrm{~b}$ \\
\hline & Pelikan $\mathrm{F}_{1}$ & $0.42 \mathrm{~b}$ & $4.71 \mathrm{~b}$ & $4.79 \mathrm{a}$ & $0.50 \mathrm{a}$ \\
\hline & $\operatorname{LSD}(\alpha=0.05)$ & 0.04 & 0.38 & 0.60 & 0.11 \\
\hline & $\mathrm{F}^{0}$ value & 5.488003 & 8.786592 & 9.683572 & 13.97932 \\
\hline & P value & 0.004957 & 0.00024 & 0.000108 & $2.5510^{-6}$ \\
\hline \multirow{6}{*}{ Year } & 2015 & $0.51 b^{*}$ & $3.70 a^{*}$ & $5.53 b^{*}$ & $0.35 \mathrm{a}^{*}$ \\
\hline & 2016 & $0.36 \mathrm{a}$ & $5.09 \mathrm{c}$ & $5.44 \mathrm{~b}$ & $0.67 \mathrm{~b}$ \\
\hline & 2017 & $0.34 \mathrm{a}$ & $4.26 \mathrm{~b}$ & $4.70 \mathrm{a}$ & $0.84 \mathrm{c}$ \\
\hline & $\operatorname{LSD}(\alpha=0.05)$ & 0.03 & 0.31 & 0.59 & 0.07 \\
\hline & $\mathrm{F}^{0}$ value & 108.482 & 57.70345 & 6.728275 & 128.6434 \\
\hline & $P$ value & $1.9410^{-30}$ & $1.4410^{-19}$ & 0.001567 & $5.8810^{-34}$ \\
\hline
\end{tabular}

*Comparison of data within the column marked with an asterisk; values designated with the same letters in columns (a.b.c...) do not statistically differ at $\mathrm{p} \leq 0.05$ (Tukey's test).
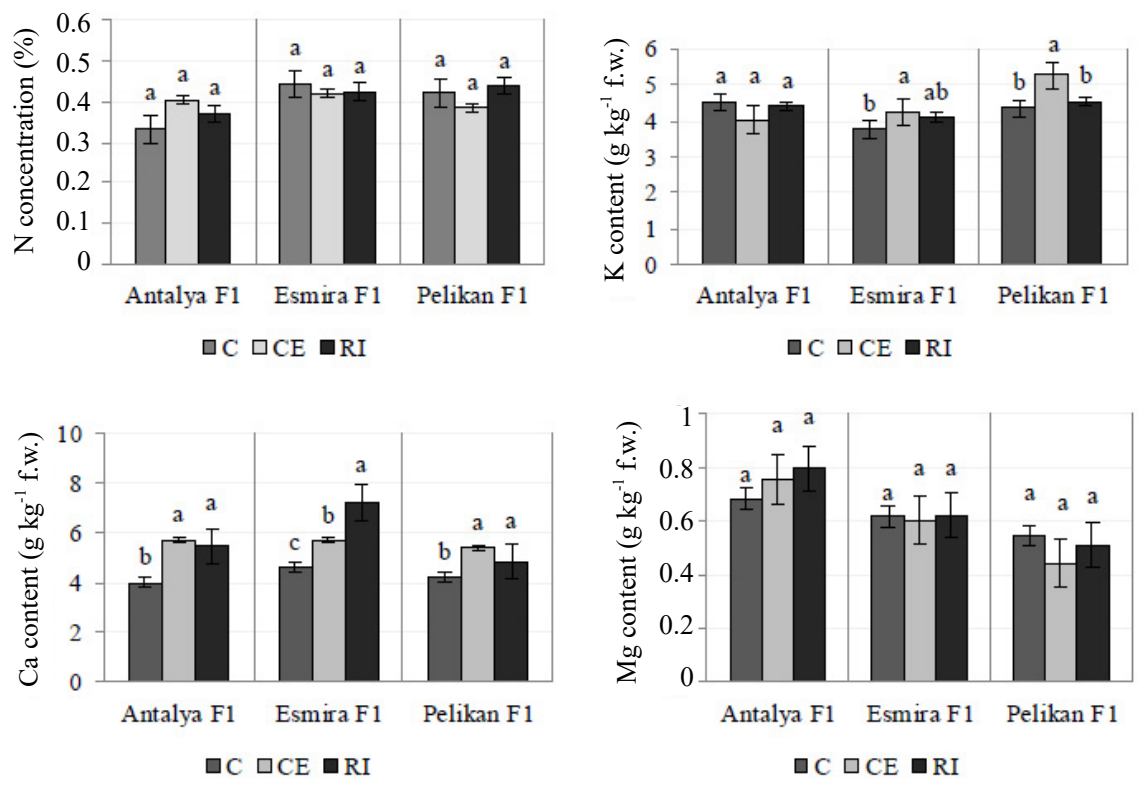

Fig. 2. Effect of MF application on leaf nutrient content in tomato plants during the growing season 2015-2017. Error bars are the standard error of the means. Notes as in Fig. 1. The letters $(a, b, c . .$.$) shown in the figure point to significant differences among the treat-$ ments at $\mathrm{p} \leq 0.05$ (Tukey's test).

The application of MF in tomato roots significantly influenced the number of tomato leaves per plant. Tomato plants inoculated with $C$. etunicatum and $R$. intraradices had 18.18-18.9 pcs plant $^{-1}$ on average, for the studied cultivars, while the control only had 16.38 pcs plant $^{-1}$ (Table 2 ). The number of leaves was also related to the cultivar used, the year of the study and the date of measurement. It was found that in 2016 and 2017, the number of leaves was higher than in 2015. A significant effect of MF on the number of tomato plant leaves was observed in the period of full fructification (22.44 pcs plant $\left.{ }^{-1}\right)$ as compared to the beginning of the fruiting period $\left(12.73\right.$ pcs plant $\left.^{-1}\right)$. 

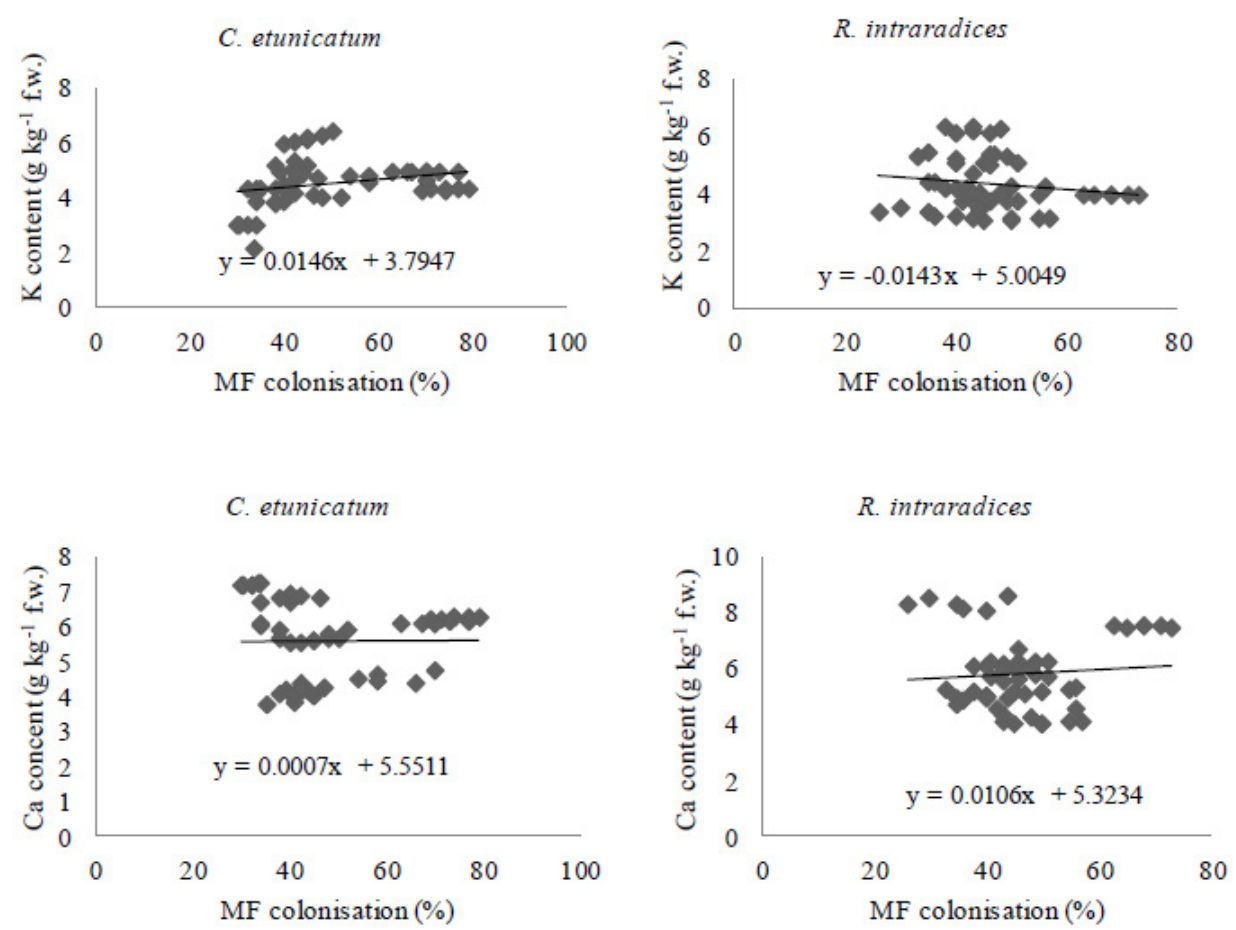

Fig. 3. Relationships between the MF colonization (\%) of roots and mean $\mathrm{Ca}$ and $\mathrm{K}$ leaf content ( $\mathrm{g} \mathrm{kg}^{-1}$ f.w.); means for combinations, years and cultivars.

Table 2. Effects of tomato mycorrhization on the length of the tomato stem and root ( $\left.\mathrm{cm}_{\text {plant }}{ }^{-1}\right)$ and on the number of tomato leaves (pcs plant $^{-1}$ ) in the growing season in 2015-2017; means for experimental combinations, years and cultivars

\begin{tabular}{|c|c|c|c|c|}
\hline & Factor & $\begin{array}{l}\text { Length of stem } \\
\qquad(\mathrm{cm})\end{array}$ & $\begin{array}{l}\text { Length of root } \\
\qquad(\mathrm{cm})\end{array}$ & $\begin{array}{l}\text { Number of leaves } \\
\quad\left(\text { pcs plant }{ }^{-1}\right)\end{array}$ \\
\hline $\begin{array}{l}\text { Experimental } \\
\text { combination }\end{array}$ & $\begin{array}{l}\text { Control } \\
C . \text { etunicatum } \\
\text { R. intraradices } \\
\text { LSD }(\alpha=0.05) \\
\mathrm{F}^{0} \text { value } \\
\mathrm{P} \text { value }\end{array}$ & $\begin{array}{c}110.97 \mathrm{a}^{*} \\
121.95 \mathrm{a} \\
119.59 \mathrm{a} \\
11.26 \\
2.894229 \\
0.056205\end{array}$ & $\begin{array}{c}44.67 \mathrm{a}^{*} \\
50.95 \mathrm{~b} \\
48.32 \mathrm{ab} \\
4.80 \\
4.835635 \\
0.009148\end{array}$ & $\begin{array}{c}16.38 \mathrm{a}^{*} \\
18.18 \mathrm{~b} \\
18.19 \mathrm{~b} \\
1.35 \\
6.58436 \\
0.001496\end{array}$ \\
\hline Cultivar & $\begin{array}{l}\text { Antalya } F_{1} \\
{\text { Esmira } F_{1}} \\
\text { Pelikan } F_{1} \\
\text { LSD }(\alpha=0.05) \\
F^{0} \text { value } \\
P \text { value }\end{array}$ & $\begin{array}{c}123.11 \mathrm{~b}^{*} \\
110.14 \mathrm{a} \\
119.26 \mathrm{ab} \\
11.24 \\
3.849729 \\
0.021875\end{array}$ & $\begin{array}{c}49.26 \mathrm{a}^{*} \\
46.91 \mathrm{a} \\
47.77 \mathrm{a} \\
4.92 \\
0.651394 \\
0.522704\end{array}$ & $\begin{array}{c}18.26 \mathrm{~b}^{*} \\
16.54 \mathrm{a} \\
17.95 \mathrm{~b} \\
1.35 \\
5.008774 \\
0.006995\end{array}$ \\
\hline Period & $\begin{array}{l}\text { BBCH } 76 \\
\text { BBCH } 89 \\
\text { LSD }(\alpha=0.05) \\
F^{0} \text { value } \\
\text { P value }\end{array}$ & $\begin{array}{c}76.35 \mathrm{a}^{*} \\
158.66 \mathrm{~b} \\
3.36 \\
2301.452 \\
1.710^{-196}\end{array}$ & - & $\begin{array}{c}12.73 \mathrm{a}^{*} \\
22.44 \mathrm{~b} \\
0.44 \\
1831.92 \\
210^{-175}\end{array}$ \\
\hline Year & $\begin{array}{l}2015 \\
2016 \\
2017 \\
\mathrm{LSD}(\alpha=0.05) \\
\mathrm{F}^{0} \text { value } \\
\mathrm{P} \text { value }\end{array}$ & $\begin{array}{c}117.90 \mathrm{a}^{*} \\
115.79 \mathrm{a} \\
118.81 \mathrm{a} \\
11.32 \\
0.205235 \\
0.81452\end{array}$ & $\begin{array}{c}51.59 \mathrm{~b}^{*} \\
45.94 \mathrm{a} \\
46.41 \mathrm{ab} \\
4.80 \\
4.768075 \\
0.009749\end{array}$ & $\begin{array}{c}16.94 \mathrm{a}^{*} \\
18.52 \mathrm{~b} \\
17.29 \mathrm{ab} \\
1.36 \\
4.118654 \\
0.016783\end{array}$ \\
\hline
\end{tabular}

*Comparison of data within the column marked with an asterisk; values designated with the same letters in columns (a.b...) do not statistically differ at $\mathrm{p} \leq 0.05$ (Tukey's test). 
$\mathrm{BBCH} 76$

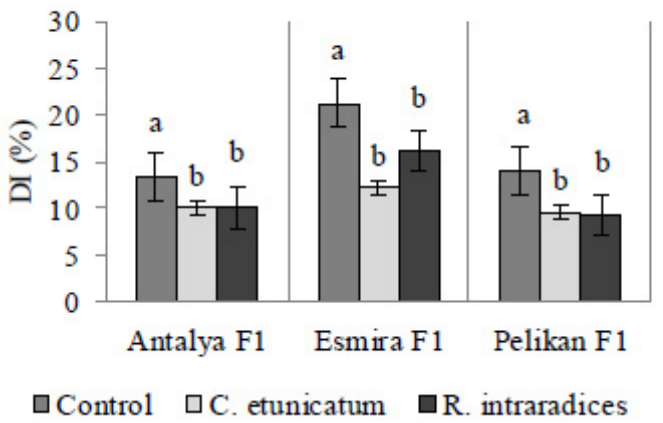

$\mathrm{BBCH} 89$

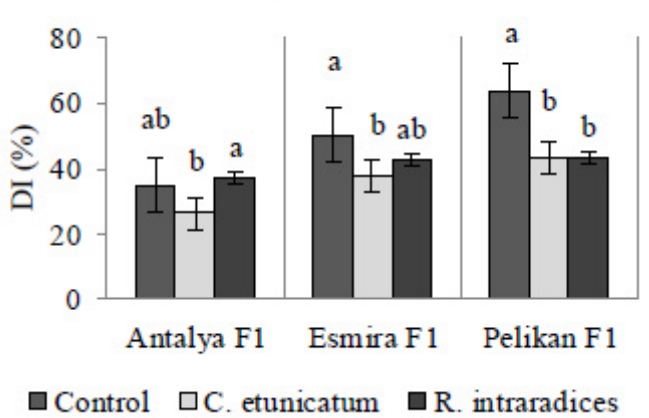

Fig. 4. Effect of mycorrhizal fungi application on the disease index of tomato plants during the growing season $2015-2017$ (for BBCH76; BBCH 89). Error bars are standard errors of the means. The letter (a,b...) shown in the figure point to significant differences among the treatments at $\mathrm{p} \leq 0.05$ (Tukey's test).

Table 3. Effects of tomato mycorrhization on fruit yield $\left(\mathrm{kg} \mathrm{m}^{-2}\right)$ in the growing season of 2015-2017; means for experimental combinations, years and cultivars

\begin{tabular}{|c|c|c|c|c|}
\hline \multirow{2}{*}{ Factor } & & \multicolumn{3}{|c|}{ Yield $\left(\mathrm{kg} \mathrm{m}^{-2}\right)$} \\
\hline & & Marketable & Diseased fruit & Other \\
\hline \multirow{6}{*}{ Experimental combination } & Control & $10.31 \mathrm{a}^{*}$ & $0.78 b^{*}$ & $0.69 \mathrm{a}^{*}$ \\
\hline & C. etunicatum & $10.92 \mathrm{a}$ & $0.38 \mathrm{a}$ & $0.60 \mathrm{a}$ \\
\hline & R. intraradices & $10.36 \mathrm{a}$ & $0.47 \mathrm{a}$ & $0.70 \mathrm{a}$ \\
\hline & $\operatorname{LSD}(\alpha=0.05)$ & 0.93 & 0.15 & 0.18 \\
\hline & $\mathrm{F}^{0}$ value & 1.485001 & 22.29628 & 0.884826 \\
\hline & $P$ value & 0.229626 & $2.9110^{-9}$ & 0.414808 \\
\hline \multirow{6}{*}{ Cultivar } & Antalya $\mathrm{F}_{1}$ & $9.88 \mathrm{a}^{*}$ & $0.29 \mathrm{a}^{*}$ & $0.42 \mathrm{a}^{*}$ \\
\hline & Esmira $\mathrm{F}_{1}$ & $11.12 \mathrm{~b}$ & $0.83 \mathrm{c}$ & $0.53 \mathrm{a}$ \\
\hline & Pelikan $\mathrm{F}_{1}$ & $10.59 \mathrm{ab}$ & $0.51 \mathrm{~b}$ & $1.04 \mathrm{~b}$ \\
\hline & $\operatorname{LSD}(\alpha=0.05)$ & 0.91 & 0.13 & 0.14 \\
\hline & $\mathrm{F}^{0}$ value & 5.218608 & 46.78324 & 65.00117 \\
\hline & $\mathrm{P}$ value & 0.006381 & $1.0510^{-16}$ & $2.3410^{-21}$ \\
\hline \multirow{6}{*}{ Year } & 2015 & $11.59 \mathrm{c}^{*}$ & $0.46 a^{*}$ & $0.74 b^{*}$ \\
\hline & 2016 & $9.45 \mathrm{a}$ & $0.64 \mathrm{~b}$ & $0.53 \mathrm{a}$ \\
\hline & 2017 & $10.54 \mathrm{~b}$ & $0.52 \mathrm{ab}$ & $0.71 \mathrm{~b}$ \\
\hline & $\operatorname{LSD}(\alpha=0.05)$ & 0.85 & 0.16 & 0.18 \\
\hline & $\mathrm{F}^{0}$ value & 17.64301 & 3.571794 & 4.305712 \\
\hline & P value & $1.210^{-7}$ & 0.030383 & 0.015099 \\
\hline
\end{tabular}

*Comparison of data within the column marked with an asterisk; values designated with the same letters in columns (a.b...) do not statistically differ at $\mathrm{p} \leq 0.05$ (Tukey's test).

The studies show a large difference in the degree of plant infection depending on the stage of plant growth and the fungus species used for mycorrhization. The $D I$ of the plants was lower at the beginning of tomato fruiting period (from 5.6 to 29.3\%) than during the full fructification (from 12.4 to $74.4 \%$ ) (Fig. 4). The inoculation of tomato plants with MF had an effect on the improvement of the plant health status. The application of mycorrhizal fungi within the rhizosphere of the plants had a significant effect on the decrease in the DI values of the plants. The only exception was 'Antalya $\mathrm{F}_{1}$ ' inoculated with $R$. intraradices, where the DI value was higher than in plants inoculated with $C$. etunicatum and in control plants. The lowest DI value was observed for all plants inoculated with C. etunicatum, but it was not statistically lower $(\mathrm{p} \leq 0.05)$ than for plants inoculated with $R$. intraradices for all cultivars, at different times of observation.

The data presented in Table 3 indicate that the application of MF had no effect on the marketable tomato yield while MF had a significant effect on the diseased fruit yield. Tomato inoculation with MF resulted in an increasing trend in the marketable yield. Inoculated plants showed an increase in the mean yield from $10.36 \mathrm{~kg} \mathrm{~m}^{-2}$ (RI) to $10.92 \mathrm{~kg} \mathrm{~m}^{-2}$ (CE) compared with the control (C), with an average yield of $10.31 \mathrm{~kg} \mathrm{~m}^{-2}$. The applied MF significantly decreased the yield of diseased fruit. The best results were obtained with the application of $C$. etunicatum, where the mean yield of diseased fruit was $0.38 \mathrm{~kg} \mathrm{~m}^{-2}(\mathrm{CE})$, while for 
the control it reached $0.78 \mathrm{~kg} \mathrm{~m}^{-2}(\mathrm{C})$. CE and RI decreased the yield of diseased fruit by 51 and $39.7 \%$ as compared with the control, respectively. Significant differences in the marketable and diseased yields were also observed between the cultivars and the years of observation (Table 3).

\section{DISCUSSION}

The present study shows that the mycorrhizal fungi studied had a beneficial effect on the nutritional status of tomato plants, expressed by the increased content of $\mathrm{Ca}$ and $\mathrm{K}$ in the leaves. The increased uptake of macro- and microelements such as potassium, nitrogen, calcium and magnesium has also been observed by other researchers (Hart et al., 2015; Wu et al., 2010; Jamiołkowska et al., 2018). An increase of mineral nutrient concentration (P, K, $\mathrm{Mg}, \mathrm{Fe}, \mathrm{Mn}, \mathrm{Zn}$, and $\mathrm{Cu}$ ) in the leaves was confirmed by Cimen et al. (2010) for tomato plants inoculated with AM Fungi. The shoots of the mycorrhizal plant had significantly higher concentrations of $\mathrm{P}, \mathrm{N}, \mathrm{K}$ and $\mathrm{Mg}$ but lower $\mathrm{Na}$ than those of non-mycorrhizal plants (Abdel-Fattah and Asrar, 2012). Other authors (Maboko et al., 2013) showed no significant concentration of minerals in the leaves of mycorrhizal plants and a lack of increased nutrient uptake by plants that were not inoculated with AM Fungi. The nutrient contents of tomato fruit varied depending on the time of inoculation with AM Fungi. Early inoculation of the plants with mycorrhizal fungi had a positive effect on the quality of the tomato fruit (Nzanza et al., 2012).

An important macronutrient in the development of tomatoes is calcium. Michałojć et al. (2015) noted that a higher level of calcium was found in the fruit of tomato plants inoculated with AM Fungi as compared with the fruit from non-mycorrhizal plants. Own research confirms this relationship. Similarly, potassium is the most important nutrient for tomato plants. It determines both the yield and quality of the cultivated plants (Afzal et al., 2015), and in the case of potassium deficiency, plant growth is inhibited. AM Fungi application improves the increase in $\mathrm{K}$ content in tomato fruit (Ordookhani et al., 2010). The increased nutrient uptake by AM Fungi may occur through two mechanisms. Mycorrhizal hyphae capture nutrients directly by increasing the absorption by extraradical hyphae, this shortens the transport route of the nutrients from the soil before they reach the roots. Direct uptake and transport of organic and inorganic $\mathrm{N}$, as well as $\mathrm{K}$ and $\mathrm{Ca}$ to the plant are affected by the extraradical hyphae of AM Fungi (George et al., 1992). The second mechanism responsible for the uptake of $\mathrm{K}, \mathrm{Ca}$ and $\mathrm{Mg}$ by mycorrhizal plants is the improved water uptake, which hastens the flow of these nutrients through the plant roots colonized by AM Fungi (Kothari et al., 1990). Mycorrhizal plants have higher root hydraulic conductivities than non-mycorrhizal plants (Ruiz-Lozano et al., 1996). Higher soluble sugar levels and electrolyte concentrations in mycorrhizal plants are respon- sible for the improved osmoregulation of these plants (Feng et al., 2002). The degree of root colonization by endomycorrhizal fungi has an influence over the type and quantity of nutrients supplied to the plant. This also causes changes in the quality and quantity of root exudates produced by the mycorrhized plants (Song et al., 2015; Treseder, 2013).

Mycorrhizal fungi participate actively in plant development (Treseder, 2013; Subramanian et al., 2006; Smith and Smith, 2011). Our results showed that the studied MF affected the root length of the investigated tomato cultivars. Where C. etunicatum was used, the roots were by $6.28 \mathrm{~cm}$ longer than for the control, while in the case of the application of $R$. intraradices the roots of this combination were by $3.65 \mathrm{~cm}$ longer as compared with the control roots (Table 2). The results achieved in present study also showed the beneficial effect of MF on the length of the tomato stems. The stems of the mycorrhizal plants were longer than those of the control plants despite a lack of statistical differences. C. etunicatum and R. intraradices significantly increased the number of leaves, whereas the plants inoculated with MF had, on average, two leaves more on each plant compared with the control (Table 2). Improvement of the vegetative growth of tomato plants may be attributed to the growing conditions and the good condition of the plants, which facilities the uptake of nutrients as well as improving the photosynthesis and transport of metabolites (Ezzo et al., 2010). Our results are consistent with the findings of many researchers (Oseni et al., 2010; Guru et al., 2011; Tanwar et al., 2013; Castillo et al., 2013). This positive effect may refer to the role of MF in enhancing the uptake of nutrients and successive water retention, which leads to improved plant growth (Treseder, 2013; Wang et al., 2008). The improved growth and the greater number of leaves of the mycorrhizal tomatoes were due to better $\mathrm{K}$ absorption by the plants, which was expressed by the increased concentration of $\mathrm{K}$ in the leaves (Table 1). Inoculation at the initial stage of plant development can promote AM symbiosis, which leads to the increased growth of plants in the nursery and improved performance after planting in the field. According to Wang et al. (2008), the higher values of the growth parameters of AM Fungi inoculated the tomatoes compared to other treatments, which were observed 31 days after plant inoculation. However, other authors show an inhibiting effect of AM Fungi on plant growth (Walling and Zabinski, 2006). This may be due to an increase in the metabolic activity of AM Fungi and a reduction in the carbon transport to the host plant (Smith and Smith, 2011). AM Fungi play different roles in plant growth and this is due to their functional diversity.

During the three-year study, our observations have shown the beneficial effect of $C$. etunicatum and $R$. intraradices on the health status of tomato plants. The severity of the disease, expressed as DI, was statistically dependent on the fungus species used for mycorrhization. The DI of the tomato plants also varied depending on the 
stage of plant growth. The potential of AM Fungi to control pathogenic fungi has been clearly described by many researchers (Joseph and Sivaprasad, 2012; Jamiołkowska et al., 2017). The positive effects of AM Fungi inoculation on the health status of plants and on the decrease of pathogen development, such as Fusarium oxysporum f. sp. lycopersici on tomato, Phytophthora parasitica, Rhizoctonia solani, F. oxysporum f. sp. cucumerinum, Rhizoctonia solani (Akköprü and Demir, 2005; Pozo et al., 2002; Berta et al., 2005; Hao et al., 2005; Kasiamdari et al., 2002), have been described. Disease inhibition is related to plant mycorrhization, changes occurring in the root system and better absorption of nutrients (Tahat and Kamaruzaman Sijam Othman, 2010).

Own data showed that the best results in the protection of tomato plants against diseases were obtained after the application of C. etunicatum (syn. Glomus etunicatum), where the value of the disease index (DI) of the studied plants was the lowest among the studied experimental combinations. The positive effect of Glomus spp. in plant protection has been described by many authors (Kobra et al., 2009). Manila and Nelson (2014) found that not only the application of one MF species but also their integration has a significant effect on the reduced incidence of wilt disease caused by Fusarium oxysporum f. sp. lycopersici in the tomato rhizosphere. In our own studies, interesting results were also obtained with $C$. etunicatum. These results were confirmed by Kobra et al. (2009) who observed a low disease index in diseased cotton plants colonized by G. etunicatum, whereas the colonization percentage of plant roots was high and therefore relevant to the health of these plants. Own studies showed the high levels of colonization of tomato roots by the mycorrhizal fungus (Fig. 1) studied, which probably have an influence over the low DI of the inoculated plants. The effectiveness of mycorrhizal inoculation and AM Fungi persistence depend on several abiotic and biotic factors in the soil, including the temperature, soil moisture, species of mycorrhizal fungus, time of mycorrhizal inoculation, levels of mycorrhizal inoculum, and also on the potential of the inoculum and the potential of the pathogen (Garmendia et al., 2004; Donkó et al., 2014). Mycorrhizal associations also induce plant resistance to abiotic stresses and soil-borne fungal pathogens (Song et al., 2015; Bi et al., 2007; Jamiołkowska et al., 2018). Mycorrhizal colonization (with Funneliformis mosseae) enhances tomato resistance to early blight by the priming a systemic defence response, and the jasmonic acid (JA) signalling pathway is essential for mycorrhizaprimed disease resistance. AM Fungi pre-inoculation has led to significant increases in the activities of $\beta-1,3$-glucanase, chitinase, phenylalanine ammonia-lyase (PAL) and lipoxygenase (LOX) in tomato leaves upon pathogen (A. alternata) inoculation (Song et al., 2015).
The positive effects of the mycorrhizal inoculation (CE, $\mathrm{RI}$ ) of tomato plants were also expressed by the decrease in the yield of the diseased fruit (Table 3). The own studies did not show any significant effect of MF on the marketable yield of the studied tomato cultivars. Similar results were reported by Michałojć et al. (2015) who noted no beneficial effect of AM Fungi on tomato yield grown in rockwool and straw. Bosco et al. (2007) showed no impact of commercial mycorrhizal formulate on the increase in the total or marketable yields of tomato. This was probably due to the natural organic soil richness. It was also suggested that an improved fruit yield could be related to an increase in pollen quantity and quality in mycorrhizal plants (Subramanian et al., 2006). A significant amount of other data, however, indicates that AM Fungi inoculation improves tomato growth and yield (Candido et al., 2015; Nzanza et al., 2012; Colella et al., 2014). Tomato plants grown in a field and inoculated with a commercial formulation of AM Fungi produced larger inflorescences, as well as a higher number of flowers and a higher total and marketable yield (Conversa et al., 2013). However, a decreased yield of diseased fruit has an indirect influence over the increase of the marketable fruit yield, which is expressed by a qualitatively better yield, this was proven in own studies. The greatest effect on the size of tomato yield was exerted by the cultivar as well as the conditions of the cultivation, and not by the application of mycorrhizal fungi.

\section{CONCLUSIONS}

1. The application of MF to the rhizosphere of tomato plants (C. etunicatum and $R$. intraradices) had a positive effect on the uptake of $\mathrm{K}$ and $\mathrm{Ca}$ by the plants, improved their growth rate and also reduced the disease index of the plants.

2. However, the treatments did not significantly increase of the marketable yield of tomatoes, but rather they decreased the yield of the diseased fruit.

3. A better uptake of macroelements from the soil (higher leaf $\mathrm{K}$ and $\mathrm{Ca}$ content) plays an important role in the yield formation and development of cultivated plants.

4. The results showed that there were significant relationships between the leaf macronutrient content and root colonization by MF, which was reflected by the improved growth rate of the plants and in the decrease of their infection rate with the pathogenic factors.

5. Among the MF species studied, improved results were obtained with the application of $C$. etunicatum as compared with $R$. intraradices for all examined features.

6. In general, our findings indicated that mycorrhizal inoculation contributes to the improved growth of tomato hybrids, it improved the health status of the plants and can be used as a safe and alternative method in ecological production. 


\section{ACKNOWLEDGEMENTS}

We would like to thank the Department of Agricultural Microbiology of the Institute of Soil Science and Plant Cultivation - National Research Institute in Puławy in Poland for providing the mycorrhizal fungi spores used in the experiment.

Conflict of interest: The Authors do not declare conflict of interest.

\section{REFERENCES}

Abdel-Fattah G.M. and Asrar A.W.A., 2012. Arbuscular mycorrhizal fungal application to improve growth and tolerance of wheat (Triticum aestivum L.) plants grown in saline soil. Acta Physiol. Plant, 34 (1), 267-277. https://doi.org/10.1007/s11738-011-0825-6

Afzal I., Hussain B., Basra S.M.A., Ullah S.H., Shakeel Q., and Kamran M., 2015. Foliar application of potassium improves fruit quality and yield of tomato plants. Acta Sci. Pol-Hortoru., 14 (1), 3-13.

Akköprü A. and Demir S., 2005. Biological control of Fusarium wilt in tomato caused by Fusarium oxysporum f. sp. lycopersici by AMF Glomus intraradices and some rhizobacteria. J. Phytopathol., 153(9), 544-550. https://doi.org/10.1111/j.1439-0434.2005.01018.x

Al-Askar A.A. and Rashad Y.M., 2010. Arbuscular Mycorrhizal Fungi: A biocontrol agent against Common Bean Fusarium Root Rot Disease. Plant Pathology J., 9, 31-38. https://doi.org/10.3923/ppj.2010.31.38

Berta G., Sampo S., Gamalero E., Massa N., and Lemanceau P., 2005. Suppression of Rhizoctonia root-rot of tomato by Glomus mossae BEG12 and Pseudomonas fluorescens A6RI is associated with their effect on the pathogen growth and on the root morphogenesis. Eur. J. Plant Pathol., 111 (3), 279-288. https://doi.org/10.1007/s10658-004-4585-7

Bi H.H., Song Y., and Zeng R.S., 2007. Biochemical and molecular responses of host plants to mycorrhizal infection and their roles in plant defence. Allelopathy J., 20(1), 15.

Błaszkowski J., 2012. Glomeromycota. In: Szafer Institute of Botany Polish Academy of Sciences, Kraków, 1-303.

Bosco M., Giovannetti G., Picard C., Baruffa E., Brondolo A., and Sabbioni F., 2007. Commercial plant-probiotic microorganisms for sustainable organic tomato production systems. In: Improving sustainability in organic and lowinput food production systems (Eds U. Niggli, C. Leifert, T. Alföldi, L. Lück, H. Willer) . Proc. 3rd QLIF Congress, Stuttgart, FiBL, Frick, 268-271.

Candido V., Campanelli G., D’Addabbo T., Castronuovo D., Perniola M., and Camele I., 2015. Growth and yield promoting effect of artificial mycorrhization on field tomato at different irrigation regimes. Sci. Hortic., 187, 35-43. https:// doi.org/10.1016/j.scienta.2015.02.033

Castillo C., Morales A., Rubio R., and Bare J.M., 2013. Interactions between native arbuscular mycorrhizal fungi and phosphate solubilizing fungi and their effect to improve plant development and fruit production by Capsicum annuum L. Afr. J. Microbiol. Res., 7 (26), 3331-3340.

https://doi.org/10.5897/ajmr2012.2363
Cimen I., Pirinc V.E.D.A.., Doran I., and Turgay B., 2010. Effect of soil solarization and arbuscular mycorrhizal fungus (Glomus intraradices) on yield and blossom-end rot of tomato. Int. J. Agric. Biol., 12, 551-555.

Colella T., Candido V., Campanelli G., Camele I., and Battaglia D., 2014. Effect of irrigation regimes and artificial mycorrhization on insect pest infestations and yield in tomato crop. Phytoparasitica, 42(2), 235-246. https://doi.org/10.1007/s12600-013-0356-3

Conversa G., Elia A., and La Rotonda P., 2007. Mycorrhizal inoculation and phosphorus fertilization effect on growth and yield of processing tomato. Acta Hortic., 758, 333-338. https://doi.org/10.17660/actahortic.2007.758.43

Conversa G., Lazzizera C., Bonasia A., and Elia A., 2013. Yield and phosphorus uptake of a processing tomato crop grown at different phosphorus levels in a calcareous soil as affected by mycorrhizal inoculation under field conditions. Biol. Fert. Soils, 49(6), 691-703. https://doi.org/10.1007/s00374-012-0757-3

Donkó Á., Zanathy G., Ėros-Honti Z., Villangó S., and Bisztray G.D., 2014. Changes of mycorrhizal colonization along moist gradient in a vineyard of Eger (Hungary). Acta Universitatis Sapientiae Agric. Environ., 6 (1), 13-23. https://doi.org/10.2478/ausae-2014-0008

Ezzo M.I., Glala A.A., Habib H.A.M., and Helaly A.A., 2010. Response of sweet pepper grown in sandy and clay soil lysimeters to water regimes. American-Eurasian J. Agric. Environ. Sci., 8(1), 18-26.

FAOSTAT, 2014. Production crops: Tomatoes. FAOSTAT Agricultural production database. http://faostat3.fao.org.

Feng G., Zhang F. S., Li X.L., Tian C.Y., Tang C., and Rengel Z., 2002. Improved tolerance of maize plants to salt stress by arbuscular mycorrhiza is related to higher accumulation of soluble sugars in roots. Mycorrhiza, 12, 185-190. https://doi.org/10.1007/s00572-002-0170-0

Fritz M., Jakobsen I., Lyngkjaer M.F., Thordal-Christensen H., and Pons-Kühnemann J., 2006. Arbuscular mycorrhiza reduces susceptibility of tomato to Alternaria solani. Mycorrhiza, 16, 413-419. https://doi.org/10.1007/s00572-006-0051-z

Garmendia I., Goicechea N., and Aguirreolea J., 2004. Plant phenology influences the effect of mycorrhizal fungi on the development of verticillium-induced wilt in pepper. Eur. J. Plant Pathol., 110, 227-238. https://doi.org/10.1023/b:ejpp.0000019790.45397.90

George E., Häussler K., Vetterlein D., Gorgus E., and Marschner H., 1992. Water and nutrient translocation by hyphae of Glomus mosseae. Can. J. Botany, 70, 2130-2137. https://doi.org/10.1139/b92-265

Guru V., Tholkappian P., and Viswanathan K., 2011. Influence of arbuscular mycorrhizal fungi and Azospirillum co-inoculation on the growth characteristics. Nutritional content, and yield of tomato crops grown in south India. Indian. J. Fund. Appl. Life Sci., 1(4), 84-92.

Hao Z., Christie P., Qin L., Wang C., and Li X., 2005. Control of Fusarium wilt of cucumber seedlings by inoculation with an arbuscular mycorrhizal fungus. J. Plant Nutr., 28(11), 1961-1974. https://doi.org/10.1080/01904160500310997

Harrier L.A. and Watson C.A., 2004. The potential role of arbuscular mycorrhizal (AM) fungi in the bioprotection of plants against soil-borne pathogens in organic and/or other sustainable farming systems. Pest. Manag. Sci., 60(2), 149157. https://doi.org/10.1002/ps.820 
Hart M., Ehret D.L., Krumbein A., Leung C., Murchm S., Turim C., and Franken P., 2015. Inoculation with arbuscular mycorrhizal fungi improves the nutritional value of tomatoes. Mycorrhiza, 25, 359-376.

https://doi.org/10.1007/s00572-014-0617-0

Jamiołkowska A., Księżniak A., Gałązka A., Hetman B., Kopacki M., and Skwaryło-Bednarz B., 2018. Impact of abiotic factors on development of the community of arbuscular mycorrhizal fungi in the soil. Int. Agrophys., 32, 133-140. https://doi.org/10.1515/intag-2016-0090

Jamiołkowska A., Księżniak A., Hetman B., Kopacki M., Skwaryło-Bednarz B., Gałązka A., and Thanoon A.H., 2017. Interactions of arbuscular mycorrhizal fungi with plants and soil microflora. Acta Sci. Pol-Hortoru., 16(5), 89-95. https://doi.org/10.24326/asphc.2017.5.9

Joseph P.J. and Sivaprasad P., 2012. The potential of arbuscular mycorrhizal associations for biocontrol of soilborne diseases. In: Biocontrol potential and its exploitation in sustainable agriculture: crop diseases, weeds and nematodes (Eds R.K. Upadhyay, K.G. Mukerij, B. Chamola). Springer Science Business Media, New York, 139-153. https://doi.org/10.1007/978-1-4615-4209-4 10

Jung S.C., Martinez-Medina A., Lopez-Raez J.A., and Pozo M.J., 2012. Mycorrhiza-induced resistance and priming of plant defenses. J. Chem. Ecol., 38 (6), 651-664. https://doi.org/10.1007/s10886-012-0134-6

Kabała C., Charzyński P., Chodorowski J., Drewnik M., Glina B., Greinert A., Hulisz P., Jankowski M., Jonczak J., Labaz B., Lachacz A., Marzec M., Mendyk L., Musial P., Musielok Ł., Smreczak B., Sowiński P., Świtoniak M., Uzarowicz L., and Waroszewski J., 2019. Polish Soil Classification, 6th edition - principles, classification scheme and correlations. Soil Sci. Annual, 70(2), 71-97. https://doi.org/10.2478/ssa-2019-0009

Kapoor R., 2008. Induced resistance in mycorrhizal tomato is correlated to concentration of jasmonic acid. OnLine J. Biol. Sci., 8(3), 49-56. https://doi.org/10.3844/ojbsci.2008.49.56

Kasiamdari R.S., Smith S.E., Smith F.A., and Scott E.S., 2002. Influence of the mycorrhizal fungus, Glomus coronatum, and soil phosphorus on infection and disease caused by binucleate Rhizoctonia and Rhizoctonia solani on mung bean (Vigna radiata). Plant Soil, 238(2), 235-244. https://doi.org/10.1023/a:1014400701819

Kobra N., Jalil K., and Youbert G., 2009. Effects of three Glomus species as biocontrol agents against Verticilliuminduced wilt in cotton. J. Plant Prot. Res., 49(2), 185-189. https://doi.org/10.2478/v10045-009-0027-z

Kothari S.K., Marschner H., and George E., 1990. Effect of VA mycorrhizal fungi and rhizosphere microorganisms on root and shoot morphology, growth and water relations in maize. New Phytologist., 116, 303-311. https://doi.org/10.1111/j.1469-8137.1990.tb04718.x

Liu J., Maldonado-Mendoza I., Lopez-Meyer M., Cheung F., Town C.D., and Harrison M.J., 2007. Arbuscular mycorrhizal symbiosis is accompanied by local and systemic alterations in gene expression and an increase in disease resistance in the shoots. Plant J., 50(3), 529-544. https://doi.org/10.1111/j.1365-313x.2007.03069.x
Lopez-Ráez J.A., Verhage A., Fernandez I., Garcia J.M., Azcon-Aguilar C., Flors V., and Pozo M.J., 2010. Hormonal and transcriptional profiles highlight common and differential host responses to arbuscular mycorrhizal fungi and the regulation of the oxylipin pathway. J. Exp. Bot., 61, 2589-2601. https://doi.org/10.1093/jxb/erq089

Maboko M.M., Bertling I., and Du Plooy C.P., 2013. Arbuscular mycorrhiza has limited effects on yield and quality of tomatoes grown under soilless cultivation. Acta Agr. Scand. B-S. P., 63(3), 261-270. https://doi.org/10.1080/09064710.2012.755219

Manila S. and Nelson R., 2014. Biochemical changes induced in tomato as a result of arbuscular mycorrhizal fungal colonization and tomato wilt pathogen infection. Asian J. Plant Sci. Res., 4(1), 62-68.

Michałojć Z., Jarosz Z., Pitura K., and Dzida K., 2015. Effect of mycorrhizal colonization and nutrient solutions concentration on the yielding and chemical composition of tomato grown in rockwool and straw medium. Acta Sci. PolHortoru., 14, 15-27.

Nicola S., Tibaldi G., and Fontana E., 2009. Tomato production systems and their application to the tropics. Acta Hortic., 821, 27-34. https://doi.org/10.17660/actahortic.2009.821.1

Nzanza B., Marais D., and Soundy P., 2012. Effect of arbuscular mycorrhizal fungal inoculation and biochar amendment on growth and yield of tomato. Int. J. Agric. Biol., 14, 965-969.

Oehl F., Sieverding E., Palenzuela J., Ineichen K., and da Silva G.A., 2011. Advances in Glomeromycota taxonomy and classification. IMA Fungus, 2, 191-199. https://doi.org/10.5598/imafungus.2011.02.02.10

Ordookhani K., Khavazi K., Moezzi A., and Rejali, F., 2010. Influence of PGPR and AMF on antioxidant activity, lycopene and potassium content in tomato. Afr. J. Agric. Res., 5(10), 1108-1116.

Oseni T.O., Shongwe N.S., and Masarirambi M.T., 2010. Effect of arbuscular mycorrhiza (AM) inoculation on the performance of tomato nursery seedlings in vermiculite. Int. J. Agric. Biol., 12, 789-792.

Palenzuela J., Ferrol N., Boller T., Azcón-Aguilar C., and Oehl F., 2008. Otospora bareai, a new fungal species in the Glomeromycetes from a dolomitic shrubland in the Natural Park of Sierra de Baza (Granada, Spain). Mycologia, 100 (2), 296-305. https://doi.org/10.3852/mycologia.100.2.296

Panthee D.R. and Chen F., 2010. Genomics of fungal disease resistance in tomato. Curr. Genomics, 11(1), 30-39. https://doi.org/10.2174/138920210790217927

Paszkowski U., 2006. Mutualism and parasitism: The yin and yang of plant symbioses. Curr. Opin. Plant Biol., 9(4), 364370. https://doi.org/10.1016/j.pbi.2006.05.008

Phillips J.M. and Hayman D.S., 1970. Improved procedures for clearing roots and staining parasitic and vesicular-arbuscular mycorrhizal fungi for rapid assessment of infection. T. Brit. Mycol. Soc., 55 (1), 158-161. https://doi.org/10.1016/s0007-1536(70)80110-3

Pozo M.J. and Azcón-Aguilar C., 2007. Unraveling mycorrhiza-induced resistance. Curr. Opin. Plant Biol., 10(4), 393-398. https://doi.org/10.1016/j.pbi.2007.05.004 
Pozo M.J., Cordier C., Dumas-Gaudot E., Gianinazzi S., Barea J.M., and Azcón-Aguilar C., 2002. Localized versus systemic effect of arbuscular mycorrhizal fungi on defence responses to Phytophthora infection in tomato plants. J. Exp. Bot., 53, 525-534. https://doi.org/10.1093/jexbot/53.368.525

Pozo M.J., Van Loon L.C., and Pieterse C.M.J., 2005. Jasmonatessignals in plant-microbe interactions. J. Plant Growth Regul., 23(3), 211-222. https://doi.org/10.1007/s00344-004-0031-5

Ruiz-Lozano J.M., Azcon R, and Gomez M., 1996. Alleviation of salt stress by arbuscular-mycorrhizal Glomus species in Lactuca sativa plants. Physiol. Plantarum, 98(4), 767-772. https://doi.org/10.1111/j.1399-3054.1996.tb06683.x.

Sadasivam S. and Manickam A., 2005. Biochemical methods. 2nd edn New Age International, New Delhi.

Smith S.E. and Smith F.A., 2011. Roles of arbuscular mycorrhizas in plant nutrition and growth: new paradigms from cellular to ecosystems scales. Annu. Rev. Plant Biol., 62, 227-250. https://doi.org/10.1146/annurev-arplant-042110-103846

Song Y., Chen D., Lu K., Sun Z., and Zeng R., 2015. Enhanced tomato disease resistance primed by arbuscular mycorrhizal fungus. Front Plant Sci., 6, 786. https://doi.org/10.3389/fpls.2015.00786

Song Y.Y., Zeng R.S., Xu J.F., Li J., Shen X., and Yihdego W.G. 2010. Interplant communication of tomato plants through underground common mycorrhizal networks. PLoS ONE 5(10):e13324. http://doi.org/10.1371/journal.pone.0013324

Subramanian K.S., Santhanakrishnan P., and Balasubramanian P., 2006. Responses of field grown tomato plants to arbuscular mycorrhizal fungal colonization under varying intensities of drought stress. Sci. Hortic., 107(3), 245-253. https://doi.org/10.1016/j.scienta.2005.07.006

Tahat M.M., and Kamaruzaman Sijam Othman R., 2010. Mycorrhizal fungi as a biocontrol. Agent Plant Pathol. J., 9, 198-207. https://doi.org/10.3923/ppj.2010.198.207
Tanwar A., Aggarwal A., Kadian N., and Gupta A., 2013. Arbuscular mycorrhizal inoculation and super phosphate application influence plant growth and yield of Capsicum annuum. J. Soil Sci. Plant Nut., 13(1), 55-66. https://doi.org/10.4067/s0718-95162013005000006

Treseder K.K., 2013. The extent of mycorrhizal colonization of roots and its influence on plant growth and phosphorus content. Plant Soil, 371, 1-13. https://doi.org/10.1007/s11104-013-1681-5

Walker C., Vestberg M., and Schüßler A., 2007. Nomenclatural clarifications in Glomeromycota. Mycol. Res., 111, 253-255. https://dx.doi.org/10.1016/j.mycres.2007.02.009.

Walling S.Z. and Zabinski C.A., 2006. Defoliation effects on arbuscular mycorrhizae and plant growth of two native bunchgrasses and an invasive forb. Appl. Soil Ecol., 32(1), 111-117. https://doi.org/10.1016/j.apsoil.2005.02.017

Wang C., Li X., Zhou J., Wang G., and Dong Y., 2008. Effects of arbuscular mycorrhizal fungi on growth and yield of cucumber plants. Commun. Soil Sci. Plan., 39(3-4), 499-509. https://doi.org/10.1080/00103620701826738

Welbaum G.E., 2015. Vegetable Production and Practices. CAB International. Wallingforth. Oxfordshire, UK, 1-486.

Wenzel H., 1948. Zur erfassung des schadenausmasses in pflanzenschutzversuchen. Pflanzenschutz-Ber., 15, 81-84.

Wu Q.S., Zou Y.N., Liu W., Ye X.F., Zai H.F., and Zhao L.J., 2010. Alleviation of salt stress in citrus seedlings inoculated with mycorrhiza: changes in leaf antioxidant defense systems. Plant Soil Environ., 56(10), 470-475. https://doi.org/10.17221/54/2010-pse

Zeng R.S., 2006. Disease resistance in plants through mycorrhizal fungi induced allelochemicals. In: Allelochemical. Biological Control of Plant Pathogens and Diseases (Eds Inderjit, Mukerji K.) Disease Management of Fruits and Vegetables, Springer, Dordrecht, 2, 181-192. https://doi.org/10.1007/1-4020-4447-x_10 